\title{
Nutrient Concentration of Straw during its Degradation in the Conditions of Forest-Steppe Zone of Trans-Urals
}

\author{
Anastasiya Akhtiamova \\ Candidate of Agricultural Sciences \\ Quality Manager, Centre of Agrobiotechnology \\ Federal State Budgetary Educational \\ Institution of Higher Education \\ «Northern Trans-Ural State Agricultural University» \\ Tyumen, Russia \\ e-mail: Ahtyamova_GAUSZ@mail.ru
}

\author{
Oksana Kulyasova \\ Department of Soil Science and Agrochemistry, \\ Federal State Budgetary Educational \\ Institution of Higher Education \\ «Northern Trans-Ural State Agricultural University» \\ Tyumen, Russia \\ e-mail: oksana-2505kul@mail.ru
}

\begin{abstract}
Based on the economic reasons, the agrarians refused to apply organic fertilizers on arable land. Nowadays, to obtain high yields of agricultural crops, agrochemicals have been actively used, which led to organic matter shortage entering the soil. Straw, as a by-product, is usually removed from fields, which aggravates the situation on arable land. Moreover, this leads to deterioration of the humus state and nutrient regime of arable soil. The research objective was as follows: to study the dynamics of nutrient release from the plowed straw. The studies were carried out on the basis of Northern Trans-Ural State Agricultural University, located in the forest-steppe zone of the eastern margin of the Trans-Ural Plateau. The soil is leached chernozem, thin, formed on covering silt. The straw was collected from each area where mineral fertilizers were applied for the planned yield from 3.0 to $6.0 \mathrm{t} / \mathrm{h}$ a of grain. The straw was buried at various depths $(10$, 20 , and $30 \mathrm{~cm})$. It was established that immediately after the plowing up of plant residues in the autumn period, the nitrogen leaching was observed from the straw in the areas where fertilizer at various rates were introduced for the planned grain yield. In May, its concentration in the plowed up plant residues reaches 0.56-0.80\% by weight. In June, the nitrogen concentration in the straw increases after the microflora growth on the surface of the plant residues. Different levels of mineral nutrition do not affect the release of phosphorus and potassium from the plowed up plant residues. The main amount of phosphorus and potassium from the plowed up straw is released in the period from October to June, reaching 0.11 and $0.10 \%$, respectively.
\end{abstract}

Keywords - straw; mineral fertilizers; plant residues; mineralization; nitrogen concentration, phosphorus and potassium.

\section{INTRODUCTION}

Western Siberia is a potentially promising area for agriculture. The bioclimatic potential of this region is quite high. Calculations show that the possible yield in the foreststeppe part of Western Siberia is not less than 6.0-7.0 t/ha of grain [1]. The limiting factor in obtaining high yield of grain crops is considered to be low effective fertility despite sufficient reserves of humus [2, 3, 4, 5]. This problem can be partially solved with mineral fertilizers [6]. However, they can cause a decrease in humus reserves and deterioration of soil properties [7]. Another limiting factor in the increase in grain yields in
Western Siberia is the lack of local varieties. In recent decades, this problem has been solved due to Siberian breeders and geneticists, who in a short time created new crop varieties that are adapted to the harsh climatic conditions of the West Siberian region $[8,9]$.

With the development of computer technology and the emergence of IT technologies, agricultural science and farmers have the opportunity to simulate soil and plant processes, thereby, achieving the maximum effect $[10,11]$. At present, the agriculture of Western Siberia cannot be imagined without mathematical modeling and mineral fertilizers. This is especially true regarding conservation of arable land fertility, which can decline very quickly if agriculture is not properly managed in Western Siberia.

In the territory of the Russian Federation the application of organic fertilizers is concentrated on $5 \%$ of arable land. This fact is explained by the large distance of fields from the place of preparation of organic fertilizers, making their transportation economically unprofitable $[12,13]$. In this case, plowing plant residues turn out to be an alternative. The use of straw as an organic fertilizer contributes to the enrichment of soil with nutrients requiring minimal economic costs. The straw of grain crops on average contains $0.55 \%$ nitrogen, $0.25 \%$ phosphorus and $1.15 \%$ potassium [14]. Compared to other organic fertilizers, the straw contains more carbon in its composition, which is concentrated in the most valuable fertility substances: cellulose, pentosans, hemicellulose and lignin - they are the energy substrate for soil microorganisms and the main building material for humus. The carbon content of straw is 3.5-4.0 times greater than the litter manure, which is extremely important in regulating the balance of soil organic matter.

It has already been noted that the plowed up straw leads to a decrease in yield. This fact is explained by the ratio of carbon to nitrogen in plant residues. For the process of straw decomposition to be conductive, the ratio should be 20(25):1 [15]. Therefore, to eliminate the effect of inhibition of cultivated plants, it is necessary to apply compensating doses of nitrogen fertilizers together with straw [16]. 
The use of mineral fertilizers is undoubtedly a powerful factor in increasing crop yields. However, they affect the chemical composition of straw and the activity of soil microflora. The process of decomposition of plant residues on arable land, where mineral fertilizers are applied, occurs in different ways. It makes the humus formation prediction and the development of the effective measures for soil fertility recovery difficult.

Study objective: to study the dynamics of the release of nutrients from the plowed up straw on leached chernozem.

\section{SUBJECTS AND METHODS}

The studies were carried out in the facility of the Department of Soil Science and Agricultural Chemistry of Northern Trans-Ural State Agricultural University located in the forest-steppe zone of Trans-Urals, the eastern outskirts of the Trans-Ural Plateau. The characteristics of soil of the experimental area are as follows: leached and thin chernozem with heavy and silty clay loam of granulometric composition, which was formed on carbonate covering loam.

Weather conditions during the years of study were satisfactory for the cultivation of grain crops. The air temperature for the growing season of 2015 and 2016 exceeded the average long-term values by 1.3 and 1.5 times, respectively. The amount of precipitation in 2014 and 2015 corresponded to 365 and $344 \mathrm{~mm}$, which is above the norm (by 13 and 8\%). The amount of precipitations in 2016 was $61 \mathrm{~mm}$ less than the mean multiyear values. Moreover, the nature of their distribution was uneven.

During the experiment the dynamics of the concentration of nitrogen, phosphorus, and potassium in the plowed up straw of spring wheat was studied. The straw was collected from each area where fertilizers were applied for the planned yield of spring wheat from 3.0 to $6.0 \mathrm{t} /$ ha of grain. The humus content in the arable layer $(0-30 \mathrm{~cm})$ varied from 7.65 to $9.05 \%$. In the deeper layer a decrease from 4.41 to $0.72-0.54 \%$ was observed. The humus reserves in a meter layer varied from 435 to 440 $\mathrm{t} / \mathrm{ha}$. The gross nitrogen content in the arable layer was 0.43 $0.44 \%$, in the $30-50 \mathrm{~cm}$ layer it amounted to $0.18-0.21 \%$.

15 grams of previously dried out and chopped straw $(5 \mathrm{~cm}$ long) were placed in bags of glass cloth. Then, after the main tillage was performed in the third decade of September, the straw samples were put at the depth of 10,20, and $30 \mathrm{~cm}$ (Table 1).

After removing the samples, the remnants of the earth were carefully swept away with a brush, and the straw was washed with a minimum amount of cold water. The samples were placed in a thermostat and dried to an air-dry state at a temperature of $105^{\circ} \mathrm{C}$. After that the nitrogen content was determined by the Kjeldahl method in the test straw. Phosphorus and potassium were determined by dry ashing with further dissolution in hydrochloric acid and exposure to ammonium molybdate. The results were processed with the help of Microsoft Excel.
TABLE. 1.

BOOKMARKS AND EXTRACTION OF STRAW FROM SOIL

\begin{tabular}{|l|l|l|l|l|l|}
\hline \multirow{2}{*}{ Name } & \multicolumn{5}{|c|}{ Periods of exposure } \\
\cline { 2 - 6 } & \multicolumn{1}{|c|}{$\boldsymbol{I}$} & \multicolumn{1}{c|}{ II } & \multicolumn{1}{c|}{ III } & \multicolumn{1}{c|}{ IV } & \multicolumn{1}{|l|}{} \\
\hline Bookmark & September & September & September & September & September \\
\hline Extraction & October & May & June & July & September \\
\hline $\begin{array}{l}\text { Exposure } \\
\text { period } \\
\text { (month) }\end{array}$ & 1 & 8 & 9 & 10 & 12 \\
\hline
\end{tabular}

\section{RESULTS}

Study results. The nitrogen content in plant residues of spring wheat grown at different levels of mineral nutrition varied in a wide range. When the spring wheat was cultivated in natural conditions (control) with mineral fertilizers for the planned yield of $4.0 \mathrm{t} / \mathrm{ha}$ of grain, the nitrogen content in the straw was 0.67 and $0.71 \%$, respectively (Fig. 1). The option with the planned yield of $3.0 \mathrm{t} / \mathrm{ha}$ of grain resulted in the nitrogen concentration in the straw amounting to $0.89 \%$ by weight, which is 1.3 more than the control values. The reason for such great accumulation of nitrogen in the straw of spring wheat (introduction of NPK at $3.0 \mathrm{t} / \mathrm{ha}$ of grain) is a feature of chernozem soils of Western Siberia. In the second half of summer, mineral nitrogen is being accumulated in black soils which is actively consumed by grain crops. At this time the plants begin to actively absorb nitrogen and do not have time to transform it into plastic substances of the grain.

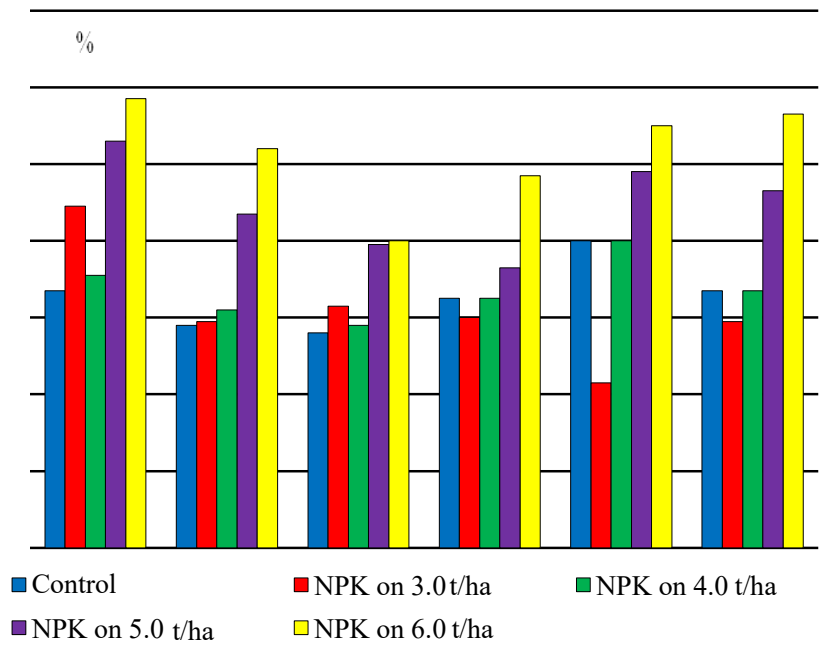

Fig. 1. The content of nitrogen in the plowed up straw $(0-30 \mathrm{~cm})$ under different levels of mineral nutrition, $\%$

The application of high doses of mineral fertilizers (NPK at 5.0 and $6.0 \mathrm{t} / \mathrm{ha}$ of grain) contributed to the additional accumulation of nitrogen in the vegetative parts of plants $(1.06$ and $1.18 \%$, respectively).

In the autumn period (exposure I), the nitrogen concentration in the plowed up straw with mineral fertilizers for the planned yield of 3.0, 5.0 and $6.0 \mathrm{t} /$ ha of grain decreased by $11-18 \%$ relative to initial values. The maximum value of nitrogen loss from the straw was revealed in the option where mineral fertilizers were applied at a planned yield of $3.0 \mathrm{t} / \mathrm{ha}$ of 
grain which is 2.6 times higher than the control one. In spring, the nitrogen content in plowed up plant residues (control and NPK at 3.0 and $4.0 \mathrm{t} /$ ha of grain) remained the same. The deviations were within the limits of the experimental error. In the experiment with the involvement of high level of mineral nutrition (NPK at 5.0 and $6.0 \mathrm{t} / \mathrm{ha}$ ), the process of leaching of nitrogen from the straw was observed, reaching 0.79 and $0.80 \%$, respectively.

In June, the nitrogen content in the plowed up straw (control) increased by $14 \%$ relative to the exposure II. A similar trend was noted in the option with the application of mineral fertilizers for the planned yield of 4.0 and $6.0 \mathrm{t} / \mathrm{ha}$ of grain. This is due to the fact that the microflora is activated; thereby, the nitrogen concentration in plant residues is getting higher. In July, the nitrogen content in the plowed up straw (control and NPK at the planned yield of 4.0-6.0 t/ha of grain) reached 0.80 $1.10 \%$ by weight. In the case of low doses of mineral fertilizers, the process of nitrogen release from straw was observed. Its content was $0.43 \%$ by weight which is 2 times less relative to the control.

After 12 months of exposure, the nitrogen concentration in the plowed up straw (control and NPK at the planned yield of 3.0 and $4.0 \mathrm{t} / \mathrm{ha}$ of grain) reached $0.59-0.67 \%$ by weight. In the case with high doses of mineral fertilizers (NPK at 5.0 and 6.0 $\mathrm{t} / \mathrm{ha}$ ) in the last 2 months of exposure the nitrogen concentration did not change, i.e. the deviations were within the experimental error.

In the process of plant development, phosphorus accumulates in the tissues. By the end of the growing season, the phosphorus content in the stems and leaves sharply decreases which is associated with its outflow from the vegetative organs and their utilization into the grain. The process of growing of spring wheat with different doses of mineral fertilizers did not have a significant effect on the phosphorus content in plant residues $-0.19-0.22 \%$ by weight (Fig. 2).

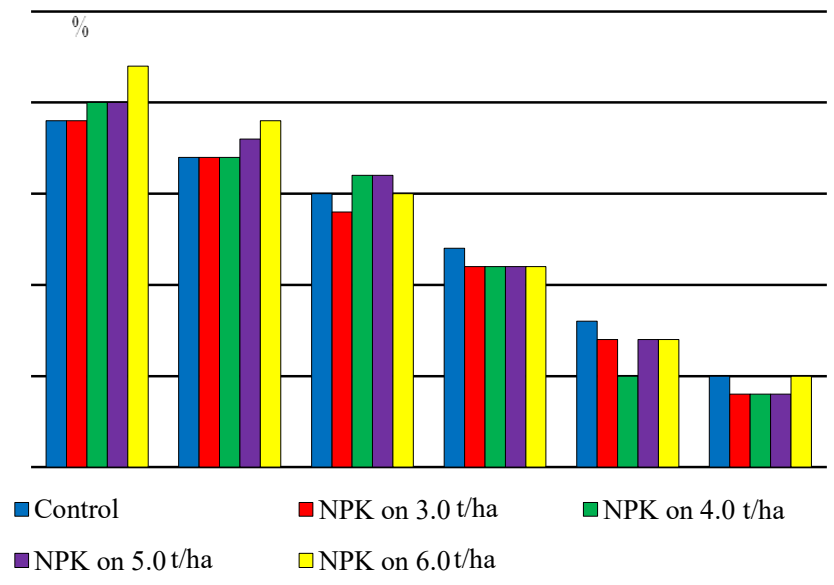

Fig. 2. The content of phosphorus in the plowed up straw $(0-30 \mathrm{~cm})$ under different levels of mineral nutrition, $\%$

In the autumn period, the phosphorus content in the plowed up straw, regardless of the option, decreases by $0.02-0.03 \%$ relative to the initial values. The same trend is observed in the release of phosphorus from plant residues from November to May. In June, the phosphorus content in the plowed straw for all options reached $0.11-0.12 \%$ by weight. By the fifth exposure period, the phosphorus content in the plowed straw reached $0.04-0.05 \%$ by weight.

Unlike nitrogen and phosphorus, potassium predominantly accumulates in the vegetative parts of plants. Therefore, when growing grain crops, it is exported with a minimum quantity of marketable products, remaining in the straw. The initial potassium content in the plant residues of spring wheat grown under natural conditions was $0.70 \%$ by weight (Fig. 3 ). The potassium content in the plowed straw with the application of mineral fertilizers for the planned yield of 3.0 and $4.0 \mathrm{t} / \mathrm{ha}$ of grain is $25 \%$ higher compared to the control $(0.93$ and $0.90 \%$, respectively). In the case of high level of mineral nutrition, the concentration of potassium in the straw is 1.10 and $1.07 \%$ by weight, which is $36 \%$ more, compared to the control. Therefore, in fields with low and medium content of mobile potassium, the straw must be plowed. This fact is confirmed by other researchers $[17,18]$

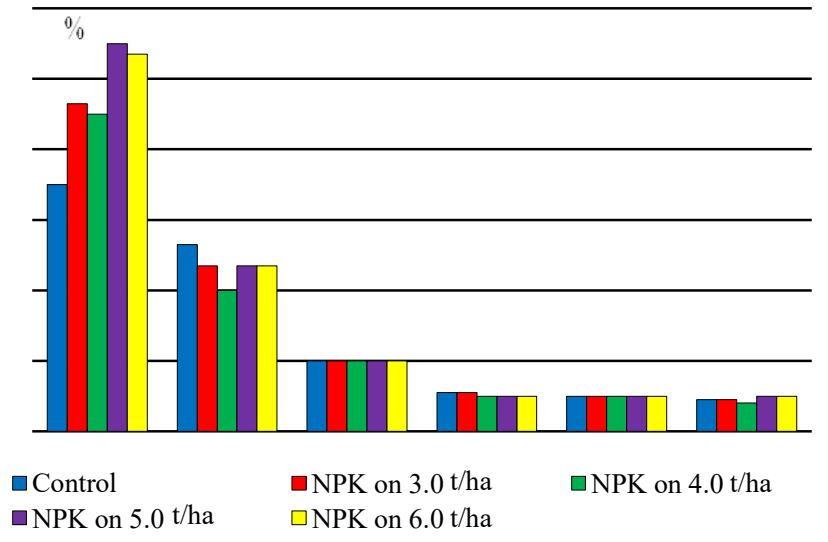

Fig. 3. The content of potassium in the plowed straw $(0-30 \mathrm{~cm})$ under different levels of mineral nutrition, $\%$

The content of potassium in the plowed up straw (control) in the first month of exposure decreased by $24 \%$ relative to the initial values, reaching $0.53 \%$ by weight. In the case with the application of mineral fertilizers for the planned yield from 3.0 to $6.0 \mathrm{t} /$ ha of grain, the potassium content in the plowed up straw decreased by 2 times relative to the initial values, which amounted to $0.40-0.47 \%$ by weight. The process of release of potassium from plant residues was observed from May to June. The decline was $0.09-0.10 \%$ relative to exposure II. Its further release from the plowed up straw was insignificant.

The plowing up of plant residues in the first month of exposure increased its rate of destruction. In the autumn period, the mass of plowed up straw, when mineral fertilizers were not applied, decreased by $11 \%$ relative to the initial value, which is 3.5 times more than the values during the process of decomposition of straw on the soil surface (Fig. 4). This fact is explained by close contact with the soil, which contributes to rapid growth of colonies of microorganisms on the surface of the plowed up straw. 


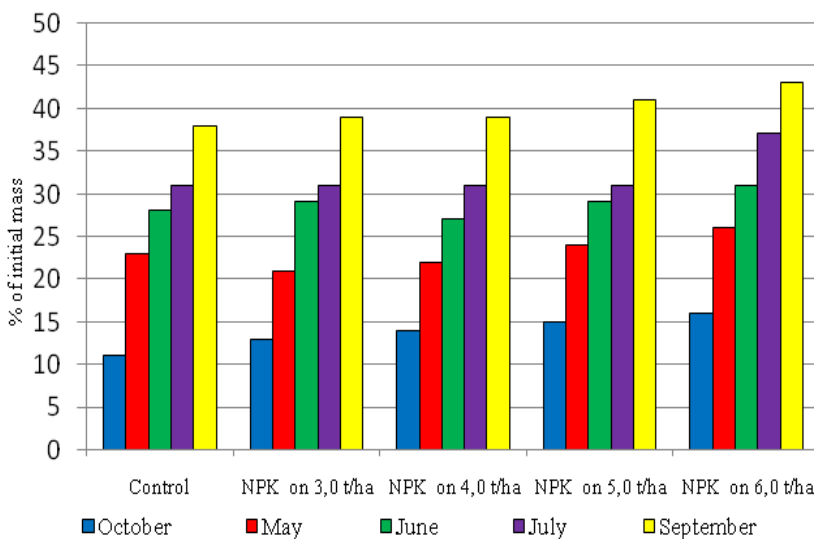

Fig. 4. Loss of mass of smelled straw at different levels of mineral nutrition $(0-30 \mathrm{~cm}), \%$ of the original mass

In the arable horizon, in the autumn period, relatively favorable conditions were created for the growth and development of microflora, while on the surface the temperature varied within a wide range. In the case when mineral fertilizers were applied for $3.0 \mathrm{t} / \mathrm{ha}$ of grain, the decrease in the mass of straw slightly increased compared to the control. A further increase in the level of mineral nutrition contributed to decomposition of the plowed up straw by 1.5 times compared to the control. This is due to the fact that the nitrogen concentration in the plowed up straw with the use of fertilizers is higher in comparison with the control. This has a stimulating effect on the development of microflora. It was found out that in the case when mineral fertilizers were applied for the planned yield from 4.0 to 6.0 t/ha of grain, the rate of decomposition of straw increased at a depth of $30 \mathrm{~cm}$, where deviations relative to the upper layers were $3-5 \%$ by weight.

Over the autumn-spring period (exposure II) the decline was $23 \%$ by weight, of which $12 \%$ was in the November-May period. This fact shows that the processes of decomposition of straw in the soil in the unfavorable period of the year are still in place. In the case when mineral fertilizers were applied for the planned yield from 3.0 to $5.0 \mathrm{t} / \mathrm{ha}$ of grain, deviations in the period from November to May were significantly higher, i.e. by $2-3 \%$ compared to the control. In the case with the maximum saturation with mineral fertilizers, the deviations were observed within the error of the experiment. The reason of it was easily destroyed organic substances consumed by microflora in the first month of the exposure.

In June, the mass of the plowed up straw decreased by $5-8 \%$ compared to the previous exposure. The mass loss reached 27$31 \%$. This was due to the high temperature and low amount of precipitation in the years of research, which adversely affected the mineralization of plant residues. In the case of maximum saturation with mineral fertilizers, the straw, plowed to a depth of $30 \mathrm{~cm}$ decomposed faster in comparison with other options under study.

The correlation analysis showed that the loss of straw mass depends on its nitrogen content $(\mathrm{r}=0.76)$. This makes it possible to conduct a regression analysis, which resulted in the following linear equation 1 :

$$
y=8.112 \times X / 32.99 \text {, }
$$

where, $y$ is the loss in straw weight, $\%$;

$X$ is the nitrogen content in plant residues, $\%$. The equation is reliable within the planned yield of up to $6.0 \mathrm{t} / \mathrm{ha}$ of grain crops.

By the exposure period IV, the decomposition of straw (control and the option with the planned yield of up to $5.0 \mathrm{t} / \mathrm{ha}$ of grain) reached the same level, i.e. the decline was $31 \%$ by weight. The application of mineral fertilizers for the planned yield of $6.0 \mathrm{t} / \mathrm{ha}$ of grain increased the destruction of plant residues by 1.6 times compared with the control. The application of mineral fertilizers for the planned yield of up to $5.0 \mathrm{t} / \mathrm{ha}$ of grain did not have such a stimulating effect compared with the dose calculated for $6.0 \mathrm{t} / \mathrm{ha}$ of grain.

During 12 months of exposure (control and the options with the planned yield of 3.0-4.0 t/ha of grain) the weight of the plowed up straw decreased by $38-39 \%$ by weight, of which $7-$ $8 \%$ was accounted for the period from August to September. The maximum saturation with mineral fertilizers (NPK at 5.0 and $6.0 \mathrm{t} / \mathrm{ha}$ ) contributed to the acceleration of mineralization of the plowed plant residues, i.e. a decrease of 41 and $43 \%$, respectively.

\section{CONCLUSION}

1. An active release of nitrogen from the plowed up straw is observed from October to May, i.e. the decrease amounted to $0.11-0.26 \%$ in comparison with the baseline values. Since June, the cellulose-decomposing microflora was developed on the surface of the plowed straw, thereby, increasing its nitrogen content.

2. From September to July of the next year, the phosphorus content in the plowed up plant residues reaches the minimum values of $0.05-0.08 \%$ by weight. The application of various doses of mineral fertilizers to the planned yield of 3.0-6.0 t/ha of grain does not affect the release of phosphorus from the straw.

3. Different content of potassium in the plowed up plant residues does not affect the dynamics of its release during the destruction of straw. In June, the potassium content in the plowed up straw reaches $0.10-0.11 \%$ by weight.

4. The decomposition rate of straw with the application of mineral fertilizers at the planned yield of up to $4.0 \mathrm{t} / \mathrm{ha}$ of grain was $38-39 \%$ for 12 months of exposure. At a high soil fertility (NPK at 5.0 and 6.0 t/ha of grain) the decomposition rate of straw increases up to $43 \%$, respectively.

5. A close correlation was established between the rate of decomposition of straw and the nitrogen concentration of plant residues $r=0.76$. The regression equation, reliable in the range of the planned yield of up to $6.0 \mathrm{t} / \mathrm{ha}$ of grain, looks as follows $y=8.112 \times X / 32.99$, where, $y$ is the loss in the straw weight, $\% ; X$ is the nitrogen content in plant residues, $\%$. 


\section{References}

[1] D.T. Degefie, E. Fleischer, O. Klemm, A.V. Soromotin, O.V. Soromotina, A.V.Tolstikov and N.V. Abramov, "Climate extremes in south western Siberia: past and future", Stoch. Environ. Res. Risk Asses, vol.. 28, 2014, pp. 2161-2173. DOI: 10.1007/s00477-014-0872-9.

[2] D.I. Eremin, "The use of modern data about the composition and properties of soil for the development of transport infrastructure of Tyumen", IOP Conference Series: Earth and Environmental Science, 2017, vol. 90, DOI: org/10.1088/1755-1315/90/1/012021.

[3] A.V. Iglovikov, "The development of artificial Phytocenosis in Environmental Construction in the far North", Procedia Engineering, vol. 165, 2016, pp. 800-805, DOI:10.1016/j.proeng.2016.11.778.

[4] D. Eremina, "The impact of transport infrastructure on ecological status of arable land in Western Siberia," MATEC Web of Conferences, vol. 170, 2018, $\quad$ pp. 05004 . DOI: https://doi.org/10.1051/matecconf/201817005004

[5] D.I. Eremin, N. A. Gruzdeva, "Influence of anthropogenic factor on microaggregate composition of gray forest soils," Siberian Bulletin of agricultural science, no. 1, 2018, pp. 28-3,. DOI: 10.26898/0370-87992018-1-4

[6] I. Kuhling, D. Redozubov, G. Broll and D. Trautz, "Impact of tillage, seeding rate and seeding depth on soil moisture and dryland spring whea yield in Western Siberia" Soil \& Tillage Research, 2017, vol. 170, pp. 4352, DOI: 10.1016/j.still.2017.02.009

[7] D.I. Eremin, "Changes in the content and quality of humus in leached chernozems of the Trans-Ural forest-steppe zone under the impact of their agricultural use," Eurasian soil science. 2016. 5, pp. 538-545. DOI: $10.1134 / \mathrm{S} 1064229316050033$

[8] A. Lyubimova, D. Eremin, "Laboratory varietal control as a guarantee of successful work of gribusiness in Russia," MATEC Web of Conferences, vol. $170, \quad 2018, \quad$ art. 04015 , https://doi.org/10.1051/matecconf/201817004015

[9] Y.P. Loginov, A.A. Kazak, L.I. Yakubyshina, T.N. Falaleeva, S.N Yashchenko and E.T. Yarova, "Breeding value of collection varieties of potato in the forest-steppe zone of the Tyumen region," Journal of Pharmaceutical Sciences and Research, no. 1, 2018, pp. 377-380.

[10] D. Eremina, "The impact of transport infrastructure on ecological status of arable land in Western Siberia," MATEC Web of Conferences, vol 170, 2018, art. 05004 DOI https://doi.org/10.1051/matecconf/201817005004

[11] D. Eremina, "IT-technologies in soil Informatics and Russian agribusiness," MATEC Web of Conferences, vol. 170, 2018, art. 04016 , DOI: https://doi.org/10.1051/matecconf/201817004016

[12] E.V. Vasilyev, "Reduction of energy consumption and improvement of environmental safety of fertilizers application by selecting an efficient radius of their transportation," Proc. of Int. Sci. Con. on Energy and energy efficiency in agricultur,. 2014, vol.2., pp. 17-20.

[13] N. Sereda, I.H. Khairullin, M.V. Petrova, "Efficiency of green manure and animal manure in regulating the balance of nutrients and humus in leached Chernozem,"Achievement of science and technology, 2017, No. 11, pp. 4-6.

[14] D.I. Eremin, A.A. Akhtyamova, "Chemical composition of plant residues of agricultural crops grown in different agricultural conditions in the forest steppe zone of Zauralye", Bulletin of Krasnoyarsk state agrarian University, 2017, vol. 125, No. 2,. pp. 32-38.

[15] E.Y. Regia, L.V. Boytsova, N.P. Buchkin, G.G. Panova, E. Regia, "The Influence of crop residues with different $\mathrm{C} / \mathrm{N}$ on the emission of nitrous oxide from sod-podzolic sandy loam soils," Soil Science, 2011, No. 10, pp. 1251-1259.

[16] A.K. Kulikov, E.A. Yashin, K.H Khisamova, A.H. Kulikova "The Effect of straw of spring wheat on the yield of barley and the balance of nutrients in typical black soil", Agrochemistry, 2017, No. 3, pp. 48-57.

[17] E.V. Nadezhkina, "Productivity and quality of spring wheat grain depending on soil acidity and mineral and organic elements", Agricultural biology, 2004, No. 1, pp. 56-61.

[18] R.B. Franklin, A.L. Mills (eds.), "The spatial distribution of microbes in the environment”, Dordrecht, Netherland, 2007, pp. 179-202. 